\title{
Social Studies in Nigeria Through the Lens of Biesta's Three Functions of Education
}

\author{
Chimezie Njoku (PhD) \\ Lawson Kemkamma Nwokah (BEd)
}

Faculty of Education, University of Port Harcourt, Nigeria

Doi: 10.19044/esj.2018.v14n7p249 URL:http://dx.doi.org/10.19044/esj.2018.v14n7p249

\begin{abstract}
This paper focuses on the examination of Social Studies Education in Nigeria with respect to the view of Gert Biesta's three functions of education; qualification, socialization, and subjectification functions. It also discussed the concepts and definitions of Social Studies, the aims, goals and objectives of social studies in Nigeria, as well as the views of education by some scholars. Furthermore, the analysis and summary of Professor Biesta's three functions of education were presented with emphasis on the socialization function. Comparison was drawn as well as the challenges of social studies in Nigeria. Recommendations were also made. Selected anthologies borrowed in the course of putting this paper together were also acknowledged.
\end{abstract}

Keywords: Biesta's Functions of Education, Social Studies Education, Challenges, Nigeria

\section{Introduction}

Social Studies is primarily concerned with human relationships. It concerns knowledge of how man is influenced by his environment, and how he in turn alters his environment to satisfy individual and group needs. It is about how men attempts to deal with certain pertinent problems, issues, and questions arising from his use or misuse of his environment as well as how he draws upon his experiences to plan for the future. All over the globe, education remains the most potent tool for nation building because it involves integration and serves as an instrument "par excellence" for effecting national development.

Despite the fact that the National Policy on Education has accorded Social Studies education a place of prominence, yet Social Studies is still grappling with its thorny march to its establishment in Nigeria's education institutions. Indeed, the general public in Nigeria has made a lazy and distorted 
image of what Social Studies in our schools involve, particularly, when there is no consensus among the teachers of the subject.

\section{The Concept of Education in Nigeria}

Education in Nigeria involves the overall development of an individual in such a way that the person will be of best to himself and to the society he belongs. Education therefore entails:

(i) A life-long process;

(ii) A social process - it takes place in the society;

(iii) A worthwhile process- education is inherently good;

(iv) An understanding of the knowledge transmitted;

(v) The knowledge and understanding that could transform one's outlook of life positively.

In support of education as a process, Peters quoted in Nwokah (2013) maintains that education is a process by which children are initiated into what is worthwhile. Thus, for him, education is basically initiation; that is, initiation into the values of the society and the young ones are from time to time initiated into these values. The implication of this definition is that education as a worthwhile venture should be intentionally transmitted in a morally acceptable manner. It would be a logical contradiction to say that a man had been educated, and that he had in no way changed for the better; or that in educating his son, a man was attempting nothing that was worthwhile.

Educational process can be transmitted formally or informally. Every society is concerned about the education of its young. Thus, this can be seen in the amount of time spent in planning such educational programmes, the increasing attention paid to the process, and the commitment of public funds towards the endeavor.

A good understanding of the concept of education will take us back in history to the origin of the word. The word "education" originated from two Latin words - Educere and Educare. The first word "educere" means to draw out or lead out. The second word "educare" means to nourish, bring up or raise. Thus, education could be said to mean to draw or lead out, to nourish, bring up and to raise up. Based on these two words, Osokoya in OmieibiDavids (2011) defined education as the leading out of the in-born powers and potentialities of the individual in the society, and the acquisition of skills, attitudes and competencies necessary for self-realization and coping with life's problems.

However, this definition connotes two things. The first is that individuals are born with certain innate qualities so that no one could be said to be completely without any human or creative qualities. It is these innate qualities that Osokoya refers to as in-born powers and potentialities that are being drawn or led out. This individual could, however, be or not be aware of 
these innate qualities and thus, has to be helped to their utmost realization in order to be effective within the society and be useful to himself. This explains the first word "educere". The second connotation of the definition is that there are skills and qualities which the individual needs but does not have them at the proper level, these he has to learn.

Osokoya's definition goes further to tell us the purpose of education. Education he says is to enable the individual cope with life's problems and attain self-realization. The process of acquiring education to cope with life's problems means that it equips us with knowledge and competencies to face the issues of everyday living. These has to do with providing basic needs such as food, clothes, shelter; have good health, a job, and living peacefully with other members of the society.

Acquiring education for self-realization means that it enables us attain whatever level we regard as the ultimate or what makes a complete and fulfilled person. This is different from person to person, and society to society.

\section{Gert Biesta's Three Functions of Education}

Gert Biesta is a professor of education in the Department of Education, Brunel University London; he was born on the $21^{\text {st }}$ of March 1957 in Rotterdam, Netherlands. Biesta identified three functions that education systems perform. He called them; Qualification functions, Socialization functions, and Subjectification functions. He is of the opinion that a major function of education lies in the qualification of children, young people, and adults. To Biesta, education lies in providing people with the Knowledge, skills and understanding, and often also, with the dispositions and forms of judgment that allows them do something ranging from specific (like training for a particular job or profession or the training of a particular skill or technique) to the much more general (such as an introduction to modern culture, or the teaching of life skills).

However, the three functions are examined below;

\section{Qualification Functions}

The qualification function of education according to Biesta is, without doubt, one of the major functions of organized education (schooling). The qualification function is, however, not restricted to preparation for the world of work, but providing students with knowledge and skills is also of significant importance to political literacy which is understood as the knowledge and skills needed for citizenship and cultural literacy generally.

\section{Subjectification Function}

In his subjectification function of education, Biesta saw education as not only contributing to qualification and socialization, but it also impacts on 
what we might call "individuation" or as Biesta prefers calling it, subjectification- the process of becoming a subject. This might best be understood as the opposite of the socialization function. It is not exactly about the insertion of "new comers" into existing orders, but about ways of being that hint at independence from such orders, ways through which the individual is not simply a "specimen" of a more encompassing order.

Consequently, there is no consensus on whether all education actually contributes to subjectification. However, it is worthy of note that education always have impacts on the individual and, therefore, has an individuating "effect." Subjectification involves ways of being whereby individuals exercise their capacity to remain independent from the existing orders by challenging their uncontested insertion into these orders. For Biesta, becoming a subject primarily revolves around the process of the formation of democratic subjectivity.

\section{Socialization Functions}

His explanation here is that the socialization function has to do with the many ways in which through education, we become part of a particular social, cultural, and political "orders". Sometimes, socialization is actively pursued by educational institutions. This is with regard to the transmission of particular norms and values, in relation to the continuation of particular cultural or religious traditions, or for the purpose of professional socialization.

Suffice to say that socialization is not the explicit aim of educational programmes and practices, education certainly will have a socializing effect. Individuals through the socializing function of education are put into the existing ways of doing and being. Through this way, education plays an important role in the continuation of culture and tradition- both with regard to its desirable and its undesirable aspects. The three functions of education can therefore be represented in the form of a Venn diagram. The three are partly overlapping and the more interesting and important questions are actually about the intersections between the areas rather than the individual areas.

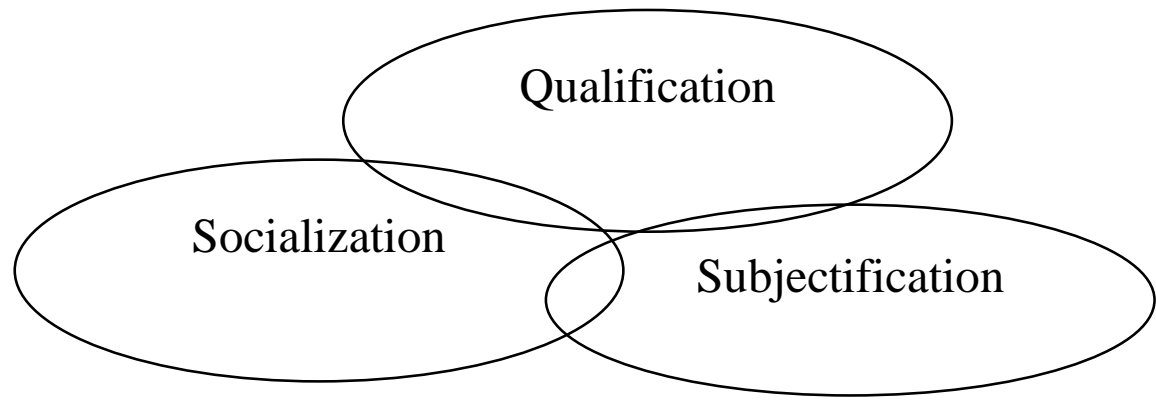

From the discourse above, the point made by Biesta suggests that when we engage in discussions of what constitutes good education, we should 
acknowledge that this is a composite question. Therefore, in order to answer this question, we need to acknowledge the different functions of education and the different potential purposes of education. An answer to the question of what constitutes good education should, therefore, always specify its view about qualification, socialization, and subjectification.

\section{Social Studies Education in Nigeria and Biesta's Three Functions of Education}

Social Studies in many countries is important and indeed a subject for political education and acculturation studies. The summary of the role which the school plays is spelt out in Gert Biesta's three functions of education: Socialization, Qualification, and Subjectification.

Socialization has been one of schools most important assignments in fostering citizens of the nation. This assignment is perhaps the most underlined assignment in contemporary schools. It is typically formulated in the overall curriculum and contains the values and behaviours that schools are meant to foster.

School plays the role of socializing the students into the society by passing on values and knowledge. The school system should equally contribute to students' qualification as citizens, helping them to advance in their civic and critical literacy. Education should give students the possibility to be independent individuals.

Social Studies is a very important subject in the school aiming at citizenship in modern democracy and focusing on human activity in the past and present societies.

First and foremost, there is need to understand what happens in a Social Studies classrooms based on the friction between the dimensions. For instance, friction arises between socialization and qualification; when the critical reviewing of societal issues conflicts with the legitimizing of democratic values and institutions (Apple, Anu and Ganding 2009 in Johan 2015). If teachings focus on the failings of the state such as the miscarriages of justice, how does that affect young peoples' perceptions of society and the legitimacy of the liberal democracy?

Secondly, we need to conceptualize what a balanced Social Studies education could and should look like in relation to the three dimensions. Looking at the comments of Peter Seixas' 2012 in Johan 2015 question on history of education: what does it mean to teach students to think about our society in a way that is appropriate for society, pedagogically sound, and true to the most current practices in the disciplines? The understanding of subject knowledge, for instance through disciplinary procedural knowledge, provides a key if the desire is to qualify students' understanding of our society, in both past and present perspectives. 
In citizenship education terms, a connection between past, present, and future can offer students a way to develop a deeper understanding of societies. However, it is important to underline that the subjects within Social studies have different sets of tools for achieving an understanding of the world and its societies. All these sets of subject knowledge are needed in order to advance students' ideas about societal issues.

Social studies shows us how all that happens in the society are related to one another. It, therefore, prepares one to be able to work together as a member of the same group. This group grows from family to school, to the entire community, state, country, and the world. Since many problems of the society are related, Social Studies education teaches as well as enlightens students on how to use knowledge and experiences to solve problems.

Social Studies education is comparable to the traditional form of education given in African societies. It is culturally relevant and real; it is functional by inculcating specific social and practical skills; it is continuous and lifelong; it is comprehensive and wholesome.

\section{Challenges of Social Studies Education in Nigeria}

There are several challenges facing Social Studies in Nigeria. Thus, few of them are discussed below.

The first challenge is the challenge of understanding as well as the differences among Social Studies educators about the concept and definition of the subject. This situation does not help the development of the subject and its general introduction at all the levels of our education system.

Another challenge is the fewness of the number of Universities offering Social Studies Programme. Only very few universities in the country offers programmes in Social Studies education. The fact that many students who do it in Colleges of Education or other Institutions cannot offer it in the universities makes the students regard it as a blind alley. This situation inhibits the developments of the subject in the country.

Also, apathy from members of the Public is another challenge. Most members of the public do not appear to understand why Social Studies should be introduced into our school system. They do not know the purpose it is meant to serve; neither do they know its potentials. They continue to ask questions like: what is this Social Studies all about? Nwosu in Nmom (2002) sees this as a lack of understanding of the subject matter.

\section{Conclusion and Recommendation}

Critical analysis of Biesta's functions of education reveals that Social Studies training and indeed Social Studies as a subject unarguably occupies a sensitive place at all levels of the Nigeria education system. It is recognized to be so because it is a core subject taught at both the primary and junior 
secondary levels. It is also taught at senior secondary as either citizenship or civic education and at the tertiary Institutions as citizenship education or civic education under the General Studies Curriculum. Nevertheless, the numerous challenges facing this subject make it very difficult for the nation to benefit from its numerous potentials.

The introduction of Social Studies in Nigerian schools is as a result of the reflection of rapidly altering circumstances of social, economic, and political life within the country. The goals of Social Studies are concerned with rapid social change, changing values, general pluralism, and other factors with which today's students will eventually have to deal with. Our world is increasingly automated, impersonal, and computerized. Nigeria is part and parcel of this changing world. In this era of political and social mobilization for a greater happier and more just tomorrow, no school subject can be more relevant than Social Studies.

In view of the discussion above, these few recommendations were made;

1. Nigerians should realize that education is the major instrument for change. Since this is true, no matter the negative perception held about Nigeria and its people, the problem can be solved if all Nigerians will develop a positive perception towards Nigeria.

2. Social Studies education as a change agent should be taken seriously and be given a chance to achieve its objectives. In addition, only trained Social Studies teachers should be allowed into the Social Studies classroom.

\section{References:}

1. Amaele, S., \& Amaele, P.E. (2010). Teacher education in contemporary society. Port Harcourt, Nigeria. Rodi.

2. Biesta, G. (2010). What is education for? Retrieved on 22/12/2016 from www.educationmuseum.wordprocess.com/2012/03/22/gertbiesta-qualification-socialization-subjectification/

3. Igwe, R.U. (2008). Contemporary issues in social studies. Port Harcourt,Nigeria. Chadik

4. Johan, S. (2015). Social studies as socialization, qualification and subjectification: Being a paper prepared for panel "Citizens still in school: Motivations for political participation”. ECPR's General conference.

5. Mezieobi, K. A. (2013). Social studies curriculum. Owerri, Nigeria. Acadapeak

6. Mezieobi, K. A., Fubara, R.V. \& Mezieobi S.A. (2008). Social studies in Nigeria: teaching methods, instructional materials and resources. Owerri, Nigeria. Acadapeak . 
7. Nwanna-Nzewunwa, O.P., Girigiri, B.K. \& Okoh, C.F. (2007). Social studies: Foundations, methods and comtemporary social problems. Owerri, Nigeria. Springfield.

8. Nmom, O.C. (2002). Social studies and citizenship education. Basic social studies, an anthology. Port Harcourt, Nigeria. ABC.

9. Nwokah, L.K. (2013). The impact of social studies education on the behavior of secondary school students in EMOLGA, R/S: An unpublished undergraduate project, Ignatius Ajuru University of Education, Port Harcourt.

10. Ogunniyi, D. (2009). Spectrum social studies: for junior secondary school 1. Ibadan, Nigeria spectrum.

11. Ogunsanya, M. (1984). Introduction to methodologies of social studies. Ibadan, Nigeria. Fast.

12. Omieibi-Davids, I. (2011). Skills in effective teaching. Port Harcourt, Nigeria. Minson.

13. Orisa, A. A (2010).Culture and socialization. Port Harcourt, Nigeria. Okoga

14. Ubogu, J.E \& Vhovhen, A.O. (2002). Social studies for junior secondary schools. Benin, Nigeria. Idodo Umeh. 